years were allowed to slip by before Boulton saw his way clear to carry his plans into effect.

Without attempting to trace again the interesting story of the development of the engines with which the names of Boulton and Watt are inseparably connected, it may be said that if Boulton claims our admiration as a judge of men, an industrialist and an organiser, he also deserves recognition as one of the few manufacturers of his time who were devoted to scientific pursuits. Had he lived to-day, he would undoubtedly have been one of the keenest advocates of scientific research for industrial purposes. As a boy he studied mechanics and chemistry, in middle age he was one of the most prominent figures in the celebrated Lunar Society, which included among its members Watt, Priestley, Wedgwood, Withering, Erasmus Darwin, Keir and Galton; and when immersed in the difficulties of negotiations with Cornish miners could write: "chemistry has for some time been my hobby-horse . . . I am almost an adept in metallurgical moist chemistry. I have got all that part of Bergmann's last volume translated, and have learnt from it many new facts". Years before, in 1757, when in correspondence with Benjamin Huntsman, the pioneer of the steel industry of Sheffield, he wrote: "I hope thy Philosophic Spirit still laboureth within thee, and may it soon bring forth Fruit useful to mankind, and more particularly to thyself".

The philosophic spirit possessed Boulton all his life, and when seventy years of age and holidaymaking at Cheltenham, he must needs have his chemical apparatus so that he could make careful analysis of the waters of the place, the results of which were all duly entered in minute detail in his memorandum books.

The chief activity of the later years of Boulton were connected with the improvement in coining and the coinage of the country. He improved the processes of minting out of all recognition, and at Soho laid down a plant which for many years served as a model for this and other countries. In his enterprise he showed the same thoroughness, the same power of organisation, the same appreciation of the application of science and art to a great practical need that marked his work on the steam engine.

\title{
Obituary
}

Sir Joseph Petavel, K.B.E., F.R.S.

$\mathrm{B}^{\mathrm{n}}$ RITISH applied science suffered a grievous loss in the death of the director of the National Physical Laboratory, Sir Joseph Petavel, on March 31. Sir Joseph, who was sixty-two years of age, was second director of the Laboratory, succeeding Sir Richard Glazebrook in 1919 and surviving him by only a few months.

Sir Joseph, who was born in London on August 14, 1873, was a son of the late Rev. E. Petavel. He received his early scientific training at University College, London, under Sir Ambrose Fleming, with whom he collaborated in his first published paper, on the alternating current arc. With the aid of an 1851 Exhibition Scholarship, he then worked under Dewar for three years at the Royal Institution and Davy Faraday Laboratory, where he studied the thermal emissivity of platinum at high temperatures and pressures. In later years he had many reminiscences to tell of his experiences at the Royal Institution.

Then came Petavel's election in 1900 to the John Harling research fellowship at Owens College, Manchester, following which he became lecturer in mechanics under Schuster. He published notable contributions on very high pressures as generated, for example, by solid and gaseous explosives. In 1904 he was responsible at the St. Louis Exhibition for the management of the liquid-air plant which was shown by the British Royal Commission. Four years later, Osborne Reynolds resigned the chair of engineering, and Petavel was elected in his place as professor of engineering and director of the Whitworth Laboratories at the University of Manchester. Further out. standing papers had meanwhile been published jointly with R. S. Hutton, on electric furnace reactions under high pressures and the effect of pressure on are spectra.

About this time Petavel was developing an interest in meteorology and aeronautics, and collaborated in an investigation on kite soundings as applied to upper-air temperatures. In 1909 he became a member of the original Advisory Committee for Aeronautics, and presently took up the study of the stability of aeroplanes. His enthusiasm led him to qualify as a pilot, an accomplishment by no means free from danger with the experimental aeroplanes of those days. It was during this period that he was the victim of a serious accident which might well have proved fatal, and indeed left its mark on him all his life. When the Aeronautical Research Committee was formed in 1917, Petavel was appointed chairman of the Aerodynamics Sub-Committee and a member of several of the other sub-committees. $\mathrm{He}$ also served as vice-chairman of the main Committee for many years until his death. In these various capacities he exercised a profound influence on the progress of aeronautical research in Great Britain.

From 1911 until 1916 Petavel had been a member of the General Board of the National Physical Laboratory, and when the directorship of the 
Laboratory became vacant in 1919 , he was called to fill Glazebrook's place. The new responsibility was one which might well have daunted many men; but Petavel brought to bear all his experience and great natural powers, and has left behind him a record of devoted and successful direction which will be long remembered. He fully maintained the high traditions set by his predecessor, and under his guidance the Laboratory steadily enhanced its influence and prestige. The staff grew to nearly seven hundred strong, and the former grounds of Bushy House were expanded from twenty-three to some fifty acres, so that adequate provision was made for future exten. sions of the work of the Laboratory to meet the ever-increasing demands of industry.

Petavel was a man of tenacious views and had a highly-developed critical faculty which stood him in good stead, and which he was accustomed to apply to everything that came before him whether significant or trivial. Few men can have had so fine an eye for detail, whether as the courteous and charming host or as the head of a great Laboratory for which he slaved unremittingly, working long hours into the night. At all times, the Laboratory came first and foremost in his thoughts, and nothing was too unimportant to escape his attention among the vast ramifications of interests with which he had to deal. He always emphasised the paramount importance of ensuring the high national and international authority of a National Physical Laboratory test or investigation : the accuracy must be unquestionable. His memory was encyclopædic, accurate and long-lived, and he kept himself singularly well informed of the progress of the almost countless developments in the various departments of the Laboratory. He possessed the faculty of trenchant comment, and would infallibly diagnose the strength and the weaknesses of a scientific report or paper. He had a liking for the parable and the metaphor in speech, often combined with a turn of whimsical humour. His staff came to realise his faculty for wise counsel, and even when it was unpalatable the recipient found it tempered by the kindly smile which accompanied it.

Petavel could always be relied upon to make major and constructive contributions to the manifold problems connected with the design and layout of new and unique equipment or buildings, the erection of which went on almost unceasingly during his directorship. Among these were individual laboratories for research in high voltages, physics, acoustics and photometry, a compressed air tunnel for aerodynamical research, further wind tunnels of the open-jet type and an additional tank for testing ship models.

Petavel was made a K.B.E. in 1920, a fellow of the Royal Society in 1907, and a member of the Athenæum under Rule II in 1920. He presided over Section G (Engineering) of the British Association in 1919. His duties on Government and other committees were exceptionally heavy. Among them were numerous boards and committees of the Department of Scientific and Industrial Research, the British Electrical and Allied Industries Research Association, and the British Standards Institution. He was, or had been, a member of the National Radium Commission, the Board of Visitors of the Royal Observatory, Greenwich, and of the Engineering Board of Studies of the University of London.

Sir Joseph commonly gratified his taste for wide travel during vacations, but at home two great delights occupied his private life--Bushy House and its garden. Bushy House, the former royal residence of Queen Adelaide, which since the foundation of the Laboratory has served as the director's residence, he lovingly adorned with period furniture and transformed into a house of beauty and refinement. He gave like attention to the 200-year-old garden, which he largely remodelled, and to the grounds of the Laboratory, which he constantly sought to beautify. Each spring tens of thousands of daffodils have given delight to his visitors and staff and they will long serve as beautiful if poignant reminders of him who gave them being.

Nothing pleased Sir Joseph more than to share his house and garden with his guests, and there are very many who will treasure happy recollections of his overflowing hospitality and the spirit which prompted him to cheer his parting guests with large bunches of flowers lavishly culled from his garden. He greatly interested himself in the welfare and social activities of the staff of the Laboratory, by whom the sense of profound personal loss occasioned by his early death is felt acutely and universally from top to bottom. Many of them cherish tokens of his kindness and friendship.

Sir Joseph, who was unmarried, showed great and characteristic fortitude to the last in his painful illness. He was interred at Highgate Cemetery on April 4. A memorial service was also held at Hampton Parish Church at which the president of the Royal Society, Sir William Bragg, paid a touching and eloquent tribute to Sir Joseph's life and work.

G. W. C. Kaye.

\section{Sir Frederick Norman}

Sir Frederick Norman, who died on March 17 at Runcorn, was one of those pioneers of applied science whose life was devoted to his work and to local affairs. He was difficult to know intimately : always pleasant, well-informed and interesting, he was a man of high character and had very great local influence, particularly as a Cheshire magistrate and as chairman of the Runcorn Bench. He suffered a severe loss at the end of the Great War in the death of his only child, Stanley, a young chemist of very great promise. He was a man of great generosity to local institutions and lent a helpful hand to very many in all stations of life.

Norman, who was born on February 18, 1857, began at Wiggs Brothers' works at Runcorn, which later became part of the United Alkali Co., and he was always in command of the works on the Cheshire side of the River Mersey, which he advocated as the finest site in the world for the production of heavy chemicals. The main development of the United Alkali Co. was then on the Lancashire side, the salt, which is the basis of this industry, being in Cheshire. 